REPORTS OF MORPHOLOGY
$\begin{gathered}\text { Official Journal of the Scientific Society of Anatomists, } \\ \text { Histologists, Embryologists and Topographic Anatomists } \\ \text { of Ukraine } \\ \text { journal homepage: https://morphology-journal.com }\end{gathered}$

\title{
Sex-related features of walking with cognitive tasks
}

\author{
Moroz V.M., Yoltukhivskyy M.V., Vlasenko O.V., Moskovko G.S., Bogomaz O.V., Rokunets I.L., \\ Tyshchenko I.V., Kostyuk L.V., Suprunov K.V. \\ National Pirogov Memorial Medical University, Vinnytsya, Ukraine
}

\section{ARTICLE INFO}

Received: 18 February, 2019

Accepted: 15 March, 2019

UDC: $612.766: 612.01+612.661$

\section{CORRESPONDING AUTHOR}

e-mail: admission@vnmu.edu.ua Moroz V. M.

\begin{abstract}
The organization of walking and its disorders remain one of the most difficult sections of the physiology of the nervous system and neurology. The purpose of the work is to analyze the sexual features of the spatio-temporal parameters of the person walking and the directions of their changes in the conditions of performing additional cognitive tasks. Sex-related features of human walking with cognitive tasks are investigated. 608 individuals of both sexes aged 12-43 years were examined by GAITRite $囚$. Consistent naming of animals and consistent subtraction of 7 starting at 100 were used as cognitive tasks. Statistical processing of the obtained results was performed in the license package "STATISTICA 5.5" using parametric estimation methods. At performing the first (simpler) cognitive task in all age groups of men step length, stride length, step extremity ratio, support base, toe-in-out were increased. Temporal parameters in adolescents of both genders did not differ. Girls have longer step time, cycle time, single support, swing time and a slower velocity. The integral index of walking quality $(F A P)$ tended to decrease in all examined groups: in adolescent males by $13.3 \pm 3.9 \%$; in young men by $14.6 \pm 2.2 \%$; in adolescent women by $15.3 \pm 1.8 \%$; in young women by $14.4 \pm 1.1 \%$; in middle-aged women $7.3 \pm 4.8 \%$. Boys and girls performed more complex cognitive tasks with reduced spatial and temporal parameters (primarily by increasing the double support and swing time), the support base and toe-in-out were stable. The step cycle was rebuilt. The support base and toe-in-out remained unchanged both in boys and girls. The boys were moving at a faster velocity, taking more steps per minute. The step time right, cycle time for each leg, single support time and double support time in girls lasted much longer. FAP declined sharply by $30.4 \%$ in boys and by $33.4 \%$ in girls, indicating a major reorganization of basic mechanisms for regulating walking stability. Such a decrease in FAP leads to a decrease in the level of the balance maintaining and a decrease in body stability during movement, which means that it increases the risk of falls. A complex cognitive task led to a decrease in walking performance and a more critical decrease in the quality of walking in favor of moving forward and maintaining the balance. Thus, walking is not an automated process, but requires the use of a variety of additional CNS resources, primarily attention and cognitive resources.

Keywords: spatial parameters of walking, temporal parameters of walking, different gender groups, gait with an additional cognitive task.
\end{abstract}

\section{Introduction}

Free walking in everyday life is a prerequisite for independent and safe performance of multifaceted daily tasks, take care of yourself, maintaining social relationships and ensuring life quality. Therefore, the study of walking is of great importance for both physiologists and clinicians. There are daily situations with dual motor or cognitive tasks, such as a phone conversation while crossing a street. Walking is a complex motor and cognitive process that, when performed, integrates significant CNS resources $[2,9,11$,
12]. Elderly people [5, 9] and neurological patients [4, 28] have impaired walking while performing additional tasks. There are some studies of walking while performing additional tasks in young healthy people. In the most studies some gait indicators were studied without regard to age and gender [10].

The organization of walking and its disorders remain one of the most difficult section of nervous system physiology and neurology, not only because of the complexity and 
insufficient study of intimate mechanisms, but also methodological problems of study of walking act. The advent of modern electronic equipment allows to obtain the parameters of a person's free walking in real time and to study its changes within different experimental paradigms, created a new opportunity for comparative analysis of this motor act and opened the prospects for clinical and instrumental comparisons [1].

After analyzing 62 publications on the results of study of the cognitive tasks impact on walking parameters in 2300 people [2], the team of authors concluded that the use of the dual task methodology (walking and cognitive task) has become a leading topic for research. However, despite the growing body of research on walking and its disorders, there are a lot of unknown issues.

The purpose of the work is to analyze gender features of human walking spatio-temporal parameters and directions of their changes while performing additional cognitive tasks.

\section{Materials and methods}

608 clinically healthy individuals of both sexes were examined to study the function of normal walking and to determine the organization features of its spatio-temporal parameters and trend of changes. At the time of the study the examined individuals should not have any injuries and diseases of different systems, which could lead to changes in gait parameters. Also, the examined volunteers were not required to consume alcohol, sedatives, drugs in the last 72 hours before the study.

Distribution of the examined individuals for age groups was as follows: 69 teenagers - 36 girls (12-15 years) and 33 boys (13-16 years); 502 young people - 241 young men (1721 years) and 261 young women (16-20 years); 37 middleaged women (21-43 years).

In our studies, spatio-temporal gait parameters were studied with the use of an automated GAITRite ${ }^{\circ}$ system, produced in the USA (CIR Systems Inc., Clifton, NJ), which is a 4.2-meter-long and 1.5-meter-wide polymer track with 22,000 integrated sensor elements that respond to pressure. When walk along the track, the system scans sensors with $80 \mathrm{~Hz}$ frequency, processes them, saves and calculates walking' integral spatio - temporal parameters of the examined. In total, two trials were considered for each person. The data were combined and thus walking at a distance of 7-8 meters in each series was estimated. Spatiotemporal gait parameters were determined separately for the right and left legs. Walking studies were performed without shoes, as more accurate changes in spatio-temporal parameters were obtained [23]. We determined the following parameters: walking speed, steps number in passage of track, steps number per minute, step length, double step length, ratio of step length to the length of lower extremity, reliance (support) width, step time, step cycle time, foot transfer time, time of support, time of reliance on both feet, stepping cycle structure, integral indicator of quality, "normality" of walking - FAP.

Figure 1-4 shows graphical representation of footprints and methods for some parameters measuring, using GAITRite $\circledast$.

The following walking parameters while performing additional cognitive tasks were analyzed: 1) consistent, without repeating pronounce of name of any known animals;

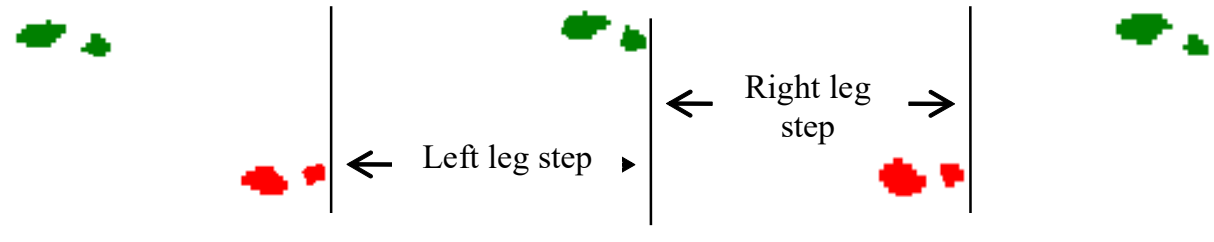

$\leftarrow \quad$ Movement direction

Fig. 1. Principle of step length determination (distance in $\mathrm{cm}$ from heel point of the previous step of one foot to the heel point of the current step of the other foot).

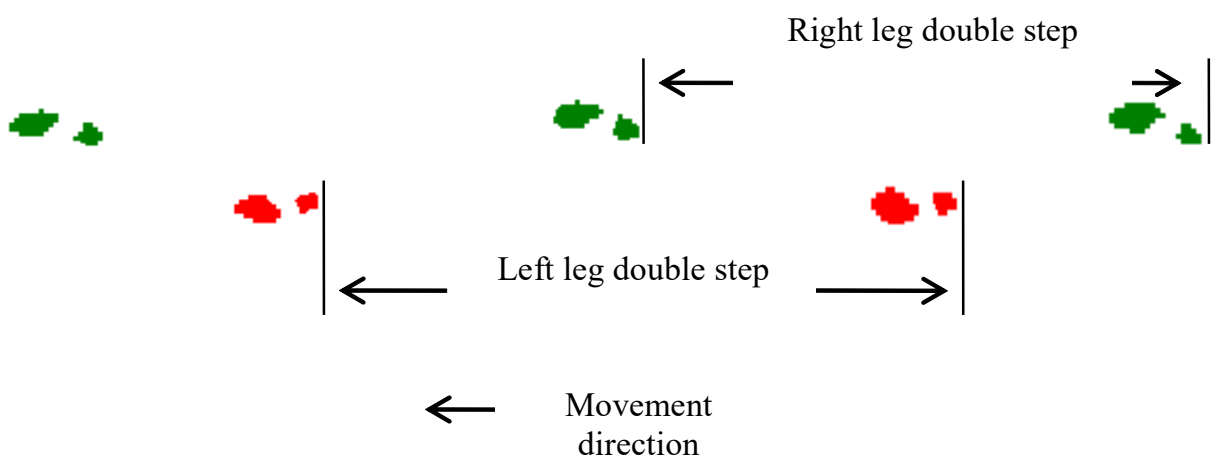

Fig. 2. Principle of double step length determination (distance in $\mathrm{cm}$ between heel points of two consecutive steps of one foot). 


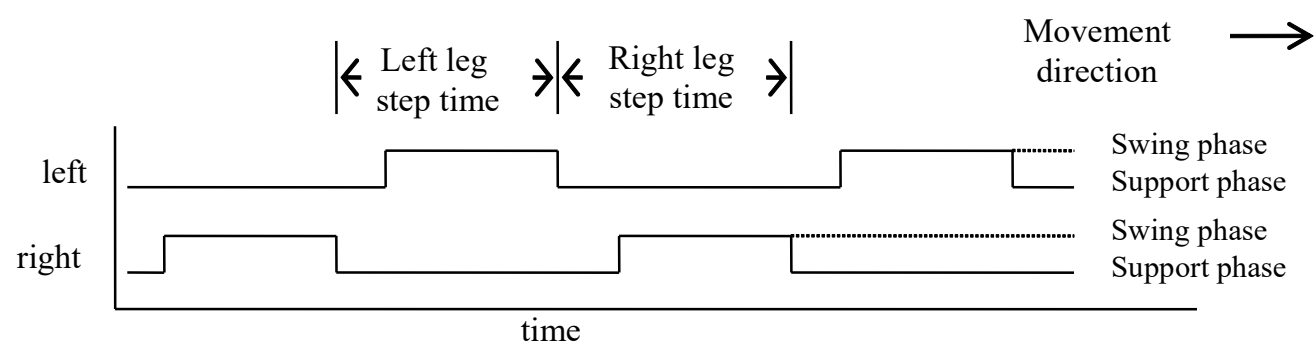

Fig. 3. Principle of step time determination (time period from the first contact of one foot to the first contact of the opposite foot).

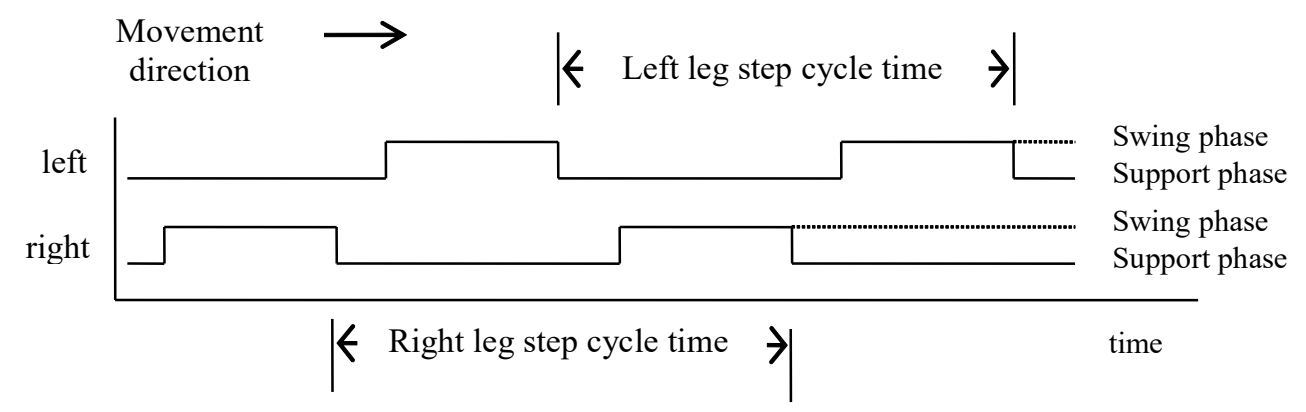

Fig. 4. Principle of step cycle time determination (time between the first contacts of two consecutive steps of one foot).

2) sequential subtraction 7 , starting at 100 . The quality of walking and the quality of cognitive task performance were assessed.

Statistical processing of the obtained results was carried out in the package "STATISTICA 5.5" (№AXXR910A374605FA) using parametric estimation methods.

\section{Results}

The spatio-temporal parameters of walking while simultaneously name known animals in male teenagers were as follows: average speed $118.6 \pm 3.5 \mathrm{~cm} / \mathrm{s}$; number of steps per minute $101.8 \pm 2.0$; step length of the right leg $69.41 \pm 1.46 \mathrm{~cm}$, left $-70.03 \pm 1.42 \mathrm{~cm}$; ratio of step length to leg length was $0.771 \pm 0.021$ on the right and $0.781 \pm$ 0.021 on the left; double step length of the right leg was $139.34 \pm 2.83 \mathrm{~cm}$, of the left one was $139.38 \pm 2.81 \mathrm{~cm}$; width of support base for the right leg $10.62 \pm 0.59 \mathrm{~cm}$, for the left $10.25 \pm 0.58 \mathrm{~cm}$; right foot turning angle is $9.231 \pm 1.041^{\circ}$, for the left one is $7.401 \pm 1.082^{\circ}$. Duration of the right and left foot steps was equal to $0.602 \pm 0.011 \mathrm{~s}$; duration of stepping cycle for the right leg was $1.191 \pm 0.032 \mathrm{~s}$, for the left leg $1.192 \pm 0.021 \mathrm{~s}$; duration of transfer of the right and left legs was the same and amounted to $0.502 \pm 0.011 \mathrm{~s}$; support (reliance) time for the right and left legs was the same and lasted $0.701 \pm 0.022 \mathrm{~s}$; duration of the single support was $0.502 \pm 0.010 \mathrm{~s}$ on both sides; reliance on both legs when performing a step, both by right and left leg lasted the same time $-0.210 \pm 0.010 \mathrm{~s}$. FAP was $83.15 \pm 3.88 \%$, which indicates a decrease in walking quality under these conditions.

In young men, the average velocity was $124.11 \pm$ $3.29 \mathrm{~cm} / \mathrm{s}$; steps number per minute was $102.09 \pm 1.68$; step length for the right leg was $72.17 \pm 1.21 \mathrm{~cm}$, for the left one was $72.98 \pm 1.18 \mathrm{~cm}$; ratio of stride length to leg length was the same on both sides and was $0.792 \pm 0.011$; double step length of the right leg was $145.57 \pm 2.32 \mathrm{~cm}$, of left one was $144.97 \pm 2.20 \mathrm{~cm}$; width of support base for the right leg was $10.48 \pm 0.48 \mathrm{~cm}$, for the left $-10.51 \pm 0.46 \mathrm{~cm}$; right foot rotation angle was $10.36 \pm 0.85^{\circ}$, for the left $-7.976 \pm 0.759^{\circ}$. Duration of the right leg steps was $0.587 \pm 0.012 \mathrm{~s}$, for the left one $0.596 \pm 0.010 \mathrm{~s}$; duration of the stepping cycle for the right leg was $1.192 \pm 0.031 \mathrm{~s}$, for the left leg $-1.188 \pm 0.019 \mathrm{~s}$; duration of right and left foot movements was the same and amounted to $0.502 \pm 0.009 \mathrm{~s}$; support time for the right leg lasted $0.701 \pm 0.010 \mathrm{~s}$, for the left $-0.693 \pm 0.008 \mathrm{~s}$; duration of the single support was $0.502 \pm 0.011 \mathrm{~s}$ on both sides; reliance on both feet when performing a step, both right and left leg lasted the same time $-0.210 \pm 0.010 \mathrm{~s}$. FAP was $82.1 \pm 2.2 \%$, which indicates a decrease in walking quality under these conditions.

The spatio-temporal parameters of walking while naming known animals in teenager girls were as follows: mean speed $103.26 \pm 4.51 \mathrm{~cm} / \mathrm{s}$; number of steps per minute $95.53 \pm 2.71$; stride length of the right leg $64.01 \pm 1.37 \mathrm{~cm}$, of the left leg $64.09 \pm 1.32 \mathrm{~cm}$; ratio of stride length to leg length was $0.761 \pm 0.019$ on the right and $0.761 \pm 0.009$ on the left; double step length of the right leg was $128.33 \pm 2.62 \mathrm{~cm}$, of the left one was $128.16 \pm 2.67 \mathrm{~cm}$; width of support base for the right leg was $7.101 \pm 0.592 \mathrm{~cm}$, for the left $-7.03 \pm$ $0.591 \mathrm{~cm}$; rotation angle for the right foot was $2.511 \pm 0.892^{\circ}$, for the left $-0.402 \pm 0.841^{\circ}$. Length of the right and left legs steps were the same and amounted to $0.654 \pm 0.021 \mathrm{~s}$; duration of stepping cycle for the right and left legs was the same and was $1.302 \pm 0.041 \mathrm{~s}$; duration of the right leg transfer was $0.543 \pm 0.019 \mathrm{~s}$, of the left $-0.536 \pm 0.020 \mathrm{~s}$; support time for the right leg was $0.768 \pm 0.029 \mathrm{~s}$, for the left 
- $0.764 \pm 0.031 \mathrm{~s}$; duration of the single support was $0.502 \pm 0.011 \mathrm{~s}$ on both sides; reliance on both feet when performing a step, both right and left leg lasted the same time $-0.310 \pm 0.010 \mathrm{~s}$. The FAP was $81.8 \pm 1.8 \%$.

In the study of spatio-temporal parameters of walking with simultaneous naming of known animals in juvenile girls we found that the average speed was equal to $98.974 \pm 3.32$ $\mathrm{cm} / \mathrm{s}$; number of steps per minute was $93.56 \pm 2.27$; step length of the right leg was $62.53 \pm 0.87 \mathrm{~cm}$, of the left leg $62.98 \pm 0.93 \mathrm{~cm}$; ratio of stride length to leg length was $0.733 \pm 0.009$ on the right and $0.741 \pm 0.011$ on the left; double step length of the right leg was $125.7 \pm 1.8 \mathrm{~cm}$, of the left one was $125.6 \pm 1.8 \mathrm{~cm}$; width of support base for the right leg was $6.619 \pm 0.494 \mathrm{~cm}$, for the left $-6.553 \pm 0.484 \mathrm{~cm}$; rotation angle of the right foot was $2.952 \pm 0.658^{\circ}$, of the left $0.501 \pm 0.687^{\circ}$. Duration of the right leg steps was $0.658 \pm 0.017 \mathrm{~s}$, of the left one was $0.681 \pm 0.020 \mathrm{~s}$; duration of the stepping cycle for the right leg was $1.341 \pm 0.039 \mathrm{~s}$, for the left $-1.337 \pm 0.041 \mathrm{~s}$; duration of the right leg transfer was $0.543 \pm 0.021 \mathrm{~s}$, of the left $-0.562 \pm 0.020 \mathrm{~s}$; support time for the right leg was $0.788 \pm 0.031 \mathrm{~s}$, for the left one $-0.769 \pm 0.018$ $\mathrm{s}$; duration of the single support was $0.568 \pm 0.021$ on the right and $0.538 \pm 0.019$ on the left; reliance on both feet when performing a step, both right and left leg lasted the same time $-0.262 \pm 0.011 \mathrm{~s}$. FAP was $82.3 \pm 1.1 \%$.

In the study of spatio-temporal parameters of walking with simultaneous naming of known animals in middle-aged women, it was found that the average speed was $101.32 \pm 4.48 \mathrm{~cm} / \mathrm{s}$; number of steps per minute was $94.24 \pm 3.11$; right leg step length was $63.68 \pm 1.12 \mathrm{~cm}$, for the left leg $63.78 \pm 1.07 \mathrm{~cm}$; ratio of stride length to leg length was $0.738 \pm 0.018$ on the right and $0.751 \pm 0.009$ on the left; double step length of the right leg was $127.5 \pm 2.1 \mathrm{~cm}$, for the left one was $127.9 \pm 2.2 \mathrm{~cm}$; width of the support base for the right leg was $6.452 \pm 0.576 \mathrm{~cm}$, for the left $-6.482 \pm 0.568 \mathrm{~cm}$; rotation angle of the right foot was $2.281 \pm 0.802^{\circ}$, for the left $-4.148 \pm 0.942^{\circ}$. Duration of the right and left foot steps was the same $-0.669 \pm 0.028 \mathrm{~s}$; duration of stepping cycle for the right leg was $1.342 \pm 0.051 \mathrm{~s}$, for the left $-1.323 \pm 0.048 \mathrm{~s}$; duration of the right and left legs transfer was $0.542 \pm$ $0.021 \mathrm{~s}$; reliance time for the right leg lasted $0.803 \pm 0.038 \mathrm{~s}$, for the left one $-0.792 \pm 0.032 \mathrm{~s}$; duration of single reliance was $0.538 \pm 0.019 \mathrm{~s}$ on both sides; reliance on both feet when performing a step, both right and left leg lasted the same time $-0.279 \pm 0.018 \mathrm{~s}$. FAP was $79.48 \pm 4.71 \%$.

There were no significant differences in cognitive task performance quality in intergender comparisons in the study groups ( $p>0.05)$.

In the study of spatio-temporal parameters of walking with simultaneous performance of more complicated cognitive task (the examined person during normal walking had to subtract consistently 7 starting from the 100 and tell the result without giving priority to any of the tasks) in adolescent boys it was found, that the average walking speed was $61.68 \pm 2.77 \mathrm{~cm} / \mathrm{s}$; steps number per minute was $61.41 \pm 2.43$. Step length of the right leg was $60.23 \pm$
$1.042 \mathrm{~cm}$, of the left leg $60.09 \pm 1.09 \mathrm{~cm}$; ratio of stride length to leg length was the same for the right and left legs and was $0.653 \pm 0.012$; the difference between step length of the right and left legs was $2.682 \pm 0.248 \mathrm{~cm}$; double step length of the right leg was $120.36 \pm 2.11 \mathrm{~cm}$, of the left one was $120.17 \pm 2.14 \mathrm{~cm}$; width of the support base for the right leg was $10.06 \pm 0.49 \mathrm{~cm}$, for the left $-10.01 \pm 0.49 \mathrm{~cm}$; rotation angle of the right foot was $8.232 \pm 0.691^{\circ}$, of the left $5.518 \pm 0.672^{\circ}$. The average length of steps for the right leg was $1.187 \pm 0.079 \mathrm{~s}$, for the left one $-1.173 \pm 0.068 \mathrm{~s}$; duration of stepping cycle for the right leg was $2.35 \pm 0.136 \mathrm{~s}$, the left $2.368 \pm 0.136 \mathrm{~s}$. Duration of the right leg transfer was $0.931 \pm 0.062 \mathrm{~s}$, of the left $-0.918 \pm 0.057 \mathrm{~s}$; reliance time for the right leg lasted $1.413 \pm 0.078 \mathrm{~s}$, for the left one $1.449 \pm 0.087 \mathrm{~s}$; duration of single reliance of the right leg was $0.921 \pm 0.058 \mathrm{~s}$, of the left one $0.928 \pm 0.059 \mathrm{~s}$; time of double reliance while performing a step by the right leg lasted $0.513 \pm 0.041 \mathrm{~s}$, by the left $-0.519 \pm 0.039 \mathrm{~s}$. The difference in step duration between the right and the left leg was $0.209 \pm 0.038 \mathrm{~s}$, and the difference in step cycles duration for both legs was $0.091 \pm 0.019 \mathrm{~s}$. In the structure of walking cycle with simultaneous performance of cognitive task in boys, the following ratios were obtained: the duration of foot transfer from the total duration of the walking cycle was $38.9 \pm 0.5 \%$ for the right leg, $38.8 \pm 0.6 \%$ for the left leg; reliance duration for the right leg was $61.1 \pm 0.5 \%$ of the total duration of stepping cycle, for the left leg $-61.2 \pm 0.6 \%$; single reliance duration of the right leg in examined boys was $39.2 \pm 0.6 \%$, of the left $-38.8 \pm 0.7 \%$ of the total duration of the respective step cycle; reliance on both feet for the stepping cycle for the right leg was $22.3 \pm 0.8 \%$, for the left leg $-22.6 \pm 0.8 \%$.

FAP of walking with simultaneous performance of cognitive task in adolescent boys was $67.6 \pm 1.7 \%$, which indicates a significant decrease in quality of walking under the given physiological paradigm.

The spatio-temporal parameters when walking with simultaneous performance of the same cognitive task in girls were as follows: average speed of movement $47.16 \pm 2.38 \mathrm{~cm} / \mathrm{s}$; per minute the girls performed $54.38 \pm 2.18$ steps; the right leg step length was $51.19 \pm 0.91$ $\mathrm{cm}$, for the left leg $50.58 \pm 0.88 \mathrm{~cm}$; ratio of stride length to leg length was the same for the right and left legs and was $0.602 \pm 0.009$; difference between step length of the right and left legs was $2.602 \pm 0.201 \mathrm{~cm}$; double step length of the right leg was $101.7 \pm 1.8 \mathrm{~cm}$, of the left one was $102.0 \pm$ $1.8 \mathrm{~cm}$; width of the support base for the right leg was $6.209 \pm 0.428 \mathrm{~cm}$, for the left leg $-6.138 \pm 0.418 \mathrm{~cm}$; the right foot rotation angle was $4.019 \pm 0.621^{\circ}$, for the left $0.501 \pm 0.658^{\circ}$. Right leg steps duration was $1.348 \pm 0.068 \mathrm{~s}$, for the left one $-1.279 \pm 0.057 \mathrm{~s}$. Stepping cycle duration for the right leg was $2.62 \pm 0.127 \mathrm{~s}$, for the left $2.581 \pm 0.117 \mathrm{~s}$; duration of the right leg transfer was $1.009 \pm 0.058 \mathrm{~s}$, of the left one $-0.948 \pm 0.048 \mathrm{~s}$; reliance duration for the right leg was $1.608 \pm 0.082 \mathrm{~s}$, for the left one $-1.638 \pm 0.079 \mathrm{~s}$; single reliance duration of the right foot was $0.947 \pm 0.049 \mathrm{~s}$, of the left one was $1.012 \pm 0.058 \mathrm{~s}$; reliance on both feet when 
performing a step with the right leg lasted $0.662 \pm 0.043 \mathrm{~s}$, left $-0.668 \pm 0.044 \mathrm{~s}$; difference in step duration between the right and left legs was $0.212 \pm 0.031 \mathrm{~s}$, and the difference in step cycles duration for both legs was $0.139 \pm 0.017 \mathrm{~s}$; foot transfer duration from the total duration of stepping cycle was $37.9 \pm 0.6 \%$ for the right leg, $36.6 \pm 0.6 \%$ for the left leg; reliance duration for the right leg was $62.2 \pm 0.6 \%$ of the total duration of stepping cycle, for the left leg it was $63.4 \pm 0.6 \%$; duration of a single reliance for the right leg was $36.5 \pm 0.6 \%$ of the total duration of stepping cycle, with the left $-38.1 \pm$ $0.7 \%$; both feet reliance for stepping cycle for the right leg was $25.7 \pm 0.8 \%$, for the left leg $-26.3 \pm 0.9 \%$. FAP when walking with simultaneous cognitive task in girls was $63.4 \pm 1.5 \%$.

In inter-gender comparison of spatio-temporal parameters of walking with simultaneous performance of more simple cognitive task (naming known animals) in teenager groups found that stride length in girls is shorter than in boys (left $9.4 \pm 1.3 \%$, right $8.5 \pm 1.2 \%)(p<0.05)$, double step length in girls is shorter than in boys (on the left by $8.9 \pm 2.8 \%$, on the right by $8.7 \pm 2.2 \%)(p<0.05)$, support base width on both sides is smaller for girls than for boys (left $45.8 \pm 8.4 \%$, right $49.9 \pm 8.3 \%)(p<0.05)$, rotation angles of both feet in girls were significantly smaller (in boys they were left $7.401 \pm 1.082^{\circ}$, right $9.231 \pm 1.041^{\circ}$, in girls on the left $0.402 \pm 0.841^{\circ}$, right $2.511 \pm 0.892$ ?, $\left.\mathrm{p}<0.001\right)$. Unlike spatial, all temporal indicators in male and female teenager groups had no statistically significant differences $(p>0.05)$.

In adolescent groups, girls had a shorter step length (by $16.0 \pm 1.87 \%$ left, by $15.5 \pm 1.7 \%$ right), double step length (by $15.5 \pm 1.7 \%$ on the left, by $15.9 \pm 1.7 \%$ on the right), support base width (left by $60.4 \pm 7.2 \%$, right by $58.6 \pm 7.4 \%$ ), rotation angles of both feet (in women left $0.501 \pm 0.687^{\circ}$, right $2.952 \pm 0.658^{\circ}$, men left $7.976 \pm 0.759^{\circ}$, right $10.36 \pm 0.85^{\circ}$, $p<0.001$ ), ratio of stride length to leg length (by $6.8 \pm 1.4 \%$ on both sides, $p<0.001$ ).

Considerable part of temporal indicators was higher in female group: step duration was longer on the left by $11.8 \pm 2.2$ $\%$, on the right by $10.6 \pm 2.3 \%$, step cycle duration on the left by $10.6 \pm 1.2 \%$, on the right by $11.3 \pm 1.2 \%$, time of single reliance on the left by $7.4 \pm 2.8 \%$, on the right by $10.7 \pm 2.7 \%$, time of transfer on the left by $10.8 \pm 2.8 \%$, on the right by $7.5 \pm 2.9 \%$, reliance duration on the left by $10.4 \pm 1.9 \%$, on the right by $11.4 \pm 2.5 \%$ ( $p<0.05)$, passage time by $27.6 \pm 4.0 \%$. Speed in women is less by $25.4 \pm 3.3 \%(p<0.001)$.

Therefore, the study of spatio-temporal parameters of walking with simultaneous performance of simpler cognitive task (naming known animals) found an increase in step time duration, step cycle, time of foot transfer, support time and double support, decrease in walking speed and number of steps per minute. Inter-gender differences in the study groups had similar characteristics: in men, greater stride and double stride length, ratio of stride length to limb length, width of support base, significantly different feet rotation angles. There were no differences in temporal parameters while comparing teenager groups of boys and girls. However, in inter-gender comparison of temporal parameters of walking with additional cognitive task in adolescent groups, differences were found in most of the parameters: women had longer stride time, stepping cycle, single support, transfer time, support time, passage time, and lower speed.

When comparing spatio-temporal parameters of walking in young men and young women with simultaneous performance of a cognitive task, which consisted of sequential subtraction 7, starting from the number 100 , such differences were established. The average movements speed of young men was statistically significantly higher $(p<0.001)$. Number of steps, taken by young men to overcome the track length was statistically significantly smaller $(p<0.001)$, and the number of steps per minute in boys was statistically significantly greater $(p<0.05)$. Among the spatial parameters in young men statistically significantly greater were the usual steps length, double steps length, ratio of steps length to the corresponding leg length, as well as the width of support base for both right and left feet and feet rotation angle ( $p<0.001$ in all cases). In boys and girls, the asymmetry of stride length for the right and left leg was not significantly different $(p>0.05)$.

Among temporal indicators statistically significantly were smaller in boys: right foot step time, step cycles time for each extremity, support time for both the right and the left leg ( $p<0.05$ in all cases) and double support time (on both feet) when performing steps by each leg $(p<0.01)$. Left foot step time, right and left foot swing time, support time only for the right or left foot, as well as the difference in the right and left foot stride time, difference in step cycles time for both legs were not significantly different ( $p>0.05$ in all cases).

In young men, in the structure of step cycle when walking with additional cognitive task the proportion of the left leg swing time and single support time for the right leg was statistically significantly greater in comparison with the total step cycle time $(p<0.01)$. The percentage of the right foot swing time, the left leg single support time, and the right leg support time did not differ significantly $(p>0.05)$. The percentage of the left leg support time $(p<0.01)$ and the percentage of double support time for each leg were significantly lower in comparison with the total step cycle time of the corresponding lower limb $(p<0.001)$.

Thus, in adolescent boys and girls while walking with simultaneous performance of cognitive task did not differ much such indicators as: asymmetry of the right and left foot steps length (among the spatial parameters); left foot step time, the right and left foot swing time, support time on the right or left foot only, as well as the difference in the right and left foot step time and step cycles time for both feet (among temporal parameters). The average walking velocity, steps number per minute, all the spatial parameters, except for the abovementioned, were statistically significantly higher in boys than in girls under the same conditions. The number of steps performed by the boys to overcome the track length and the right foot step time, step cycles time for each leg, right and left legs support time, support time on both feet 
when performing steps with each leg were less in boys. In step cycle structure when walking with a cognitive task in boys, statistically significantly higher were the proportions of the left leg swing time and right leg single support time from the total time of step cycle of the corresponding leg, and the share of the left leg support time and the share of double support time for both legs were smaller. The proportion of right foot swing time, left leg single support time, and right leg support time did not differ in stepping cycles of boys and girls while walking with simultaneous performance of a cognitive task.

In detailed analysis of actual cognitive task quality, it was found that standing in the general group of adolescents, out of 14 possible numbers to calculate, the average number of errors for them was $1.1 \pm 1.4$, which is equal to $7.9 \pm 9.8 \%$. When performing a cognitive task while walking on a track in adolescents group, the average total number of calculated numbers was $8.3 \pm 3.2$, and the average number of errors in calculations $-1.3 \pm 1.5$, which is equal to $17.4 \pm 18.3 \%$.

\section{Discussion}

Contrary to the traditional notions of anatomical and functional separation of motor systems from cognitive ones, modern research can reasonably claim that these systems are interconnected [7, 9]. The basis for motion-building is the coordinated activity of different brain systems, both for those that directly control the implementation of motor act and those related to the processes of perception, attention, and memory [17].

It should be noted that the direction of changes in walking indicators while performing the cognitive task in our studies only in some cases coincided with those, reported in scientific literature.

When analyzing the effect of more simple cognitive task (sequential without repeating naming any known animal) on spatio-temporal walking parameters, it was found that gender differences of walking parameters with performance of additional cognitive task had similar directions in all studied age groups: in men longer stride and double stride length, stride length to limb length ratio, support base width, larger foot rotation angles, what probably related to anthropometric differences. Differences in temporal parameters of walking with additional cognitive task were not detected when comparing teenager groups (boys and girls). And in inter-gender comparison of walking temporal parameters with performance of additional cognitive task in adolescent groups we revealed differences in most parameters, namely: in women longer stride time, stepping cycle time, single support time, swing time, support time, longer passage time and less speed in relation to young men groups. Such changes in adolescence are likely to be associated with not only significant anthropometric gender differences (as in adolescents) but also significant neurohumoral changes.

It should be noted that there are conflicting results of studies of cognitive tasks effect on human walking parameters. There are reports of cognitive tasks no influence on walking of young healthy people as well as on healthy elderly people [22, 24]. The authors used easy cognitive tasks as additional ones (verbal response to auditory stimulus, verbal response to visual stimulus, etc.) that required little cognitive effort, or perhaps gave priority exclusively to walking, which was studied less accurately, mostly using electronic footswitch systems or kinematic body data estimation using video cameras [18, 21]. The study of walking using miniature gyroscopes found [4] in healthy young people performing verbal speed task caused significant changes in walking, but not in cognitive task performance: walking speed decreased and step time increased, stride length parameters did not change significantly.

In our case, the cognitive component (animal naming), apparently, was such by influence force that led to changes not in all walking parameters, but changed only some temporal parameters. Thus, it can be reasonably assumed that walking temporal parameters with additional cognitive task begin to change as soon as the simplest cognitive tasks are performed, and therefore they are more labile than spatial parameters, which change as the cognitive task complexity increases. It is important that walking speed decrease in dual tasks indicates to involvement of highorder cognitive systems in speed control [2]. The authors suggest that walking speed control zones are associated with networks of high-level cognitive functions, in particular prefrontal cortex.

When walking with more complex arithmetic cognitive task, speed decreased by $52.5 \%$ in adolescent boys and $61.5 \%$ in girls. The same effect of cognitive task performance on walking speed, but less significant, was also observed in other studies [8-10, 13, 27]. Thus, reducing walking speed with simultaneous additional task is likely to be a defensive reaction to maintain movement stability. On the other hand, there are data that slow walking speed, which is often accompanied by step cycle time variability increase, contributes to gait instability [17]. Therefore, in our case, in the context of simultaneous arithmetic counting walking, decrease in speed may indicate that such walking becomes less stable than normal walking. Instability may be associated with less effective walking control in speed decrease. In our studies, it was revealed that not only usual step and double step length decreases (right foot in boys by $14.9 \%$, in girls by $19.6 \%$; left foot in boys by $15.2 \%$, in girls by $20.8 \%$ ), but also steps length, performed by each leg to corresponding leg length ratio (in boys by $14.5 \%$, in girls by $20 \%)$.

Invariability of support base width and feet rotation angles in both boys and girls may indicate that functional support base dimensions in normal walking is sufficient to maintain posture and balance even in walking with simultaneous performance of cognitive task, as well as on more rigid mechanisms of these two parameters regulation.

We have determined that both in boys and in girls' 
decrease in walking speed with simultaneous calculus occurs due to increase of all without exception temporal parameters and first of all, due to increase of support time and foot swing time. With the help of special shoes, in sole of which were mounted touch sensors, we also found increase in mean step cycle time in group of healthy elderly people in walking with simultaneous counting. Although, researchers team, led by J.M. Hausdorff, in study of walking with cognitive load in healthy elderly people, found decrease in foot swing time [9].

The stepping cycle was adjusted in the direction of reducing percentage of each leg swing time and single support time for each lower extremity from their stepping cycles time (in boys by $3.9 \%$ and $3.7 \%$, respectively; in girls in average by $7.6 \%$ and $7.4 \%$, respectively), and increase in percentage of each leg support time and both legs support time in stepping cycles of corresponding lower extremities (in boys by $2.7 \%$ and $18.5 \%$, respectively, in girls by $5.2 \%$ and $34.7 \%$ respectively). Therefore, to maintain equilibrium when walking with simultaneous arithmetic task helps longer support period in the stepping cycle of such walking. Moreover, the increased instability of walking with simultaneous calculation in comparison with normal walking is indicated by the increase of asymmetries of step time (from $0.010 \pm 0.001$ to $0.210 \pm 0.040 \mathrm{~s}$ ), step cycle time (from $0.010 \pm 0.001$ to $0.100 \pm 0.020 \mathrm{~s}$ ), and girls also have an asymmetry of stride length (from $1.620 \pm 0.120$ to $2.600 \pm$ $0.200 \mathrm{~cm}$ ).

The overall quality ("normality") of walking index with simultaneous cognitive task is critically reduced by $30.4 \%$ in boys and $33.4 \%$ in girls, indicating significant reorganization of basic mechanisms of walking stability regulation with participation of spinal and super-segmental structures under the influence of powerful commands from the highest cortex centers.

It should be noted that there are conflicting results of studies of cognitive tasks effect on human walking parameters. There are reports that cognitive tasks have no influence on walking of young healthy people as well as on healthy elderly people $[19,22]$. The authors used easy cognitive tasks as additional ones that required little cognitive effort, or perhaps gave priority exclusively to walking.

Differences in spatio-temporal parameters of walking with simultaneous more complex, arithmetic cognitive task between boys and girls indicate that boys moved faster, performing more steps per minute. Right leg step time, step cycles time for each leg, support time for both right and left legs, and support time for two legs in girls was much longer than in boys. Probably, in girls the mechanisms of walking stabilization are more aimed at increasing contact time with support surface. When walking with simultaneous cognitive task, we found a certain sexual dimorphism of step cycle structure, which is not observed in ordinary walking. In boys stepping cycle, unlike girls, the percentage of double support time for each leg, as well as the percentage of left leg support time, are smaller, and the percentage of left leg swing time and right leg single support time are greater. Perhaps, in significant complications of walking conditions, young men to maintain balance prioritize a particular leg, namely the right one in our research.

When assessing changes in walking parameters, which were caused by additional task performance, it is important to keep in mind that according to spatial and temporal parameters of walking we can indirectly assess the state of CNS structures, responsible for forming walking parameters.

Dynamic walking control includes a number of critical interaction criteria: external environmental data, goals, biomechanical constraints, and sensor integration. Dynamic walking control is based on coordinated motor neurophysiological pattern, in which appropriate interaction of body segments with each other and the environment is made to ensure progress and stability while walking. State of activity of such coordinated motor pattern, step-by-step and at long intervals is also a key factor, as walking variability is a unique area that provides data on intellectual awareness of falls risk and future mobility impairment. Dynamic walking control of higher level requires adaptability in the context of additional proposed tasks. Assessment of walking data obtained is the key to a comprehensive assessment and study of dynamic walking control [6].

It is reasonably believed [15] that step length and speed are controlled by phase output from basal ganglia into additional motor area, whereas spinal cord structures and brain stem determine the rhythm.

Locomotor phase control function is performed by cerebellar loop, which includes spinal cord, cerebrospinal tract, cerebellum, and descending pathways from brain stem. Each of these descending tracts carries both tonic (nonpaternal) and phase (paternal) signals into spinal cord. These signals regulate upper and lower extremities movements by stimulation and inhibition of spinal interneurons and motoneurons activity. Change of such walking spatial parameters as stride length and double stride length, can be a sign of cerebellum pathology [26].

Closed cerebellar spinal circuits act as a control system for locomotor phase. In this case, pontomedullary reticular formation cells affect not only rhythm, but also force and phase of moving locomotor movements, increasing the importance of ventromedial system, which fibers primarily separated from vestibular nuclei, tectum, bridge and medulla oblongata reticular formation for locomotion control [6]. Based on these data, it can be predicted that changes in certain walking parameters as well as phase disturbances in overall walking pattern may indicate a shift in ventromedial system of locomotion control.

The data of our study argue the possibility of using additional tasks as a tool of isolated influence on temporal (cognitive task similar to ours in type and complexity - animal naming) and spatial (motor task) walking parameters, which allows indirectly evaluate the functional state of different parts of nervous system. 
It is important to establish the fact that support base is characterized by the highest stability and plays a key role in locomotor tasks performance in difficult walking conditions. Stability of support base is required to maintain medio-lateral and anterior-posterior stability of walking. Support base is the most stable parameter, which does not change with different walking paradigms. In our study, the abovementioned parameter did not change while performing all the additional tasks.

Thus, maintaining balance and preventing falls, which is the primary walking task, while walking with simultaneous additional tasks can be ensured by constant support base width - one of the most important components in control mechanism of balance and stability of walking.

We did not find differences in performance quality of simple cognitive task (naming animals) between gender groups. Walking quality with additional cognitive task tended to decrease in all study groups, as indicated by the results of FAP comparison. Accordingly, FAP decreased in teenager males from $96.4 \pm 4.04 \%$ to $83.14 \pm 3.9 \%$, in adolescent males from $96.7 \pm 4.9 \%$ to $82.1 \pm 2.2 \%$, in teenager women from $97.1 \pm 3.9 \%$ to $81.8 \pm 1.8 \%$, in adolescent women from $96.7 \pm 4.0$ $\%$ to $82.3 \pm 1.1 \%$, in middle-aged women from $96.8 \pm 5.3 \%$ to $89.5 \pm 4.8 \%$. Obviously, such FAP decrease proves that performing a cognitive task while walking leads to a decrease in balance level and body stability during movement, and thus increases falls risk, so significant FAP decrease can be used as a diagnostic criterion in neurological practice.

Significantly, when walking with simultaneous complex, arithmetic cognitive task, three girls refused to participate in this physiological paradigm (to perform both walking and counting) although the performance of these tasks separately, of course, did not cause any problems to them.

Decline in quality of dual tasks performing (walking and cognitive tasks) can be explained by neuropsychological theory of "resource allocation", according to which, if both tasks performed simultaneously they require the use of resources that exceed the resource of central general ability, then performing a single task, or, even, both will worsen, regardless to the specific nature of the tasks. According to the modified version of the theory of "resource allocation", due to the ability of attention to be distributed, when it is dispersed to perform two tasks that need attention, it may deteriorate, even if the capacity of the resource is not exceeded [16, 25].

There is an opinion that articulation may affect late control in healthy people [3]. Since naming animals requires coordination between the processes of articulation, phonation and respiration, this additional task can also be considered as a complex motor task. Sequent subtraction 7 and result pronunciation also requires coordination between the processes of articulation, phonation and respiration, and this additional task can also be seen as a complex motor task. Naming animals while walking can be classified as a rhythmic activity. In the scientific literature there are some data that, while performing two rhythmic tasks of different frequencies, their powerful interference can occur [14] Obviously, in our study, the rhythmic nature of naming animals could interfere with walking rhythm and thus provoke significant changes in walking.

You can reasonably argue about the interference of walking and counting in our study. We found a significant decrease in walking quality (decrease in FAP indices) as well as in arithmetic counting (critical increase in the number of errors in calculations from $7.9 \pm 9.8 \%$ in standing to $17.4 \pm 18.3 \%$ while walking). This can be explained by the neuropsychological theory of "resource allocation", according to which, if both tasks performed simultaneously they require the use of resources that exceed the resource of central general ability, then performing a single task, or, even, both will worsen, regardless to the specific nature of the tasks. According to the modified version of the theory of "resource allocation", due to the ability of attention to be distributed, when it is dispersed to perform two tasks that need attention, it may deteriorate, even if the capacity of the resource is not exceeded [16].

And according to the theory of the "bottle neck", the performance of two similar tasks reduces their performance quality $[9,20]$. But it is essential, that studies on cognitive tasks influence on walking process show that the latter change walking even when the cognitive task does not have a motor component [8].

Thus, in practically healthy boys and girls, walking regulation with simultaneous performance of such cognitive task (arithmetic counting) is carried out by reducing spatial and increasing temporal parameters of walking, constant width of support base and foot rotation angle, restructuring of step cycle towards reducing the percentage of swing time and single support time and increase in percentage of support time for each leg and support time on both legs. We have used one of the complex cognitive tasks that needs maximum attention and memory. As a result, the quality of both walking and cognitive performance decreased, but the quality of counting (more than twice) declined more critically, in favor of moving forward and maintaining balance. Thus, the examined individuals subconsciously gave priority to walking.

This is coordinated with the "first pose strategy" put forward by A. Shumway-Cook, according to which, in case of increasing threat of falling, the subject prefers late control or stability of walking over the performance of additional, secondary task in order to reduce risk of falling and injury [24].

It should be emphasized that changes in spatiotemporal pattern of walking with simultaneous performance of certain tasks depend not only on task nature, but also increase in accordance with its difficulty. The greater impact of complex cognitive task on walking can be related to the mechanisms of information processing in CNS. Probably, in case of arithmetic counting, they were activated to a greater extent. In addition, counting is dependent on operative brain memory and thus directly on executive function. Competition 
for executive function resource of two simultaneously performed tasks in walking conditions with additional cognitive task turned out to be quite intense.

Of course, the influence of articulation component on walking as a part of our chosen cognitive task cannot be excluded.

Therefore, regulation of spatio-temporal parameters of walking depends on the work of all levels of nervous system. The basic spatio-temporal pattern is initiated by central generators of spinal cord rhythm, whose work is set up and modulated by supra-segmental structures, and layered commands from cerebral cortex can substantially change the basic pattern by creating an appropriate spatio-temporal model of walking.

\section{References}

[1] Abbruzzese, L. D., Rao, A. K., Bellows, R., Figueroa, K., Levy, J., Lim, E., \& Puccio, L. (2014). Effects of manual task complexity on gait parameters in school-aged children and adults. Gait \& posture, 40(4), 658-663. doi: 10.1016/ j.gaitpost.2014.07.017

[2] Al-Yahya, E., Dawes, H., Smith, L., Dennis, A., Howells, K., \& Cockburn, J. (2011). Cognitive motor interference while walking: a systematic review and meta-analysis. Neuroscience \& Biobehavioral Reviews, 35(3), 715-728. doi: 10.1016/..neubiorev.2010.08.008

[3] Dault, M. C., Yardley, L., \& Frank, J. S. (2003). Does articulation contribute to modifications of postural control during dualtask paradigms? Cognitive Brain Research, 16(3), 434-440. doi: 10.1016/s0926-6410(03)00058-2

[4] Dubost, V., Annweiler, C., Aminian, K., Najafi, B., Herrmann, F. R., \& Beauchet, O. (2008). Stride-to-stride variability while enumerating animal names among healthy young adults: result of stride velocity or effect of attention-demanding task? Gait \& posture, 27(1), 138-143. doi: 10.1016/j.gaitpost.2007.03.011

[5] Dubost, V., Kressig, R. W., Gonthier, R., Herrmann, F. R., Aminian, K., Najafi, B., \& Beauchet, O. (2006). Relationships between dual-task related changes in stride velocity and stride time variability in healthy older adults. Human movement science, 25(3), 372-382. doi: 10.1016/j.humov.2006.03.004

[6] Earhart, G. M. (2013). Dynamic control of posture across locomotor tasks. Movement disorders, 28(11), 1501-1508. doi: $10.1002 / \mathrm{mds} .25592$

[7] Gonzales, J. U., James, C. R., Yang, H. S., Jensen, D., Atkins, L., Thompson, B. J., ... \& O'Boyle, M. (2016). Different cognitive functions discriminate gait performance in younger and older women: A pilot study. Gait \& posture, 50, 89-95. doi: 10.1016/ j.gaitpost.2016.08.021

[8] Grabiner, M. D., \& Troy, K. L. (2005). Attention demanding tasks during treadmill walking reduce step width variability in young adults. Journal of neuroengineering and rehabilitation, 2(1), 25. doi: $10.1186 / 1743-0003-2-25$

[9] Hausdorff, J. M., Schweiger, A., Herman, T., Yogev-Seligmann, G., \& Giladi, N. (2008). Dual-task decrements in gait: contributing factors among healthy older adults. The Journals of Gerontology Series A: Biological Sciences and Medical Sciences, 63(12), 1335-1343. doi: https://doi.org/10.1093/ gerona/63.12.1335

[10] Hollman, J. H., Kovash, F. M., Kubik, J. J., \& Linbo, R. A. (2007). Age-related differences in spatiotemporal markers of gait stability during dual task walking. Gait \& posture, 26(1), 113-

\section{Conclusions}

1. The regulation of space-time parameters of walking depends on the work of all levels of the nervous system. The basic spatio-temporal pattern is initiated by the central generators of the spinal rhythm, whose work is set and modulated by supra-segmental structures, and the layered commands from the cerebral cortex can significantly change the basic pattern by creating an appropriate spatiotemporal model of walking.

2. Given the changes in quantitative and qualitative indicators of walking in different physiological paradigms, we can confidently state that walking is not an automated process, but requires the use of a variety of additional CNS resources, especially attention and cognitive resources.

119. doi: $10.1016 /$ j.gaitpost.2006.08.005

[11] Hung, Y. C., Gill, S. V., \& Meredith, G. S. (2013). Influence of dual-task constraints on whole-body organization during walking in children who are overweight and obese. American journal of physical medicine \& rehabilitation, 92(6), 461471. doi: 10.1097/PHM.0b013e31828cd59d

[12] Hung, Y. C., Meredith, G. S., \& Gill, S. V. (2013). Influence of dual task constraints during walking for children. Gait \& posture, 38(3), 450-454. doi: 10.1016/j.gaitpost.2013.01.009

[13] Lajoie, Y., Teasdale, N., Bard, C., \& Fleury, M. (1996). Upright stand- ing and gait: are there changes in attentional requirements related to normal aging? Exp.ging. Res., 22(2), 185-198. doi: 10.1080/03610739608254006

[14] Montero-Odasso, M., Verghese, J., Beauchet, O., \& Hausdorff, J. M. (2012). Gait and cognition: a complementary approach to understanding brain function and the risk of falling. Journal of the American Geriatrics Society, 60(11), 2127-2136. doi: 10.1111/j.1532-5415.2012.04209.x

[15] Parihar, R., Mahoney, J. R., \& Verghese, J. (2013). Relationship of gait and cognition in the elderly. Current translational geriatrics and experimental gerontology reports, 2(3), 167173. doi: 10.1007/s13670-013-0052-7

[16] Posner, M. I., Sheese, B. E., Odludas, Y., \& Tang, Y. (2006). Analyzing and shaping human attentional networks. Neural networks, 19(9), 1422-1429. doi: 10.1016/j.neunet.2006.08.004

[17] Priest, A. W., Salamon, K. B., \& Hollman, J. H. (2008). Agerelated differences in dual task walking: a cross sectional study. Journal of neuroengineering and rehabilitation, 5(1), 29. doi: $10.1186 / 1743-0003-5-29$

[18] Qu, X. (2014). Age-related cognitive task effects on gait characteristics: do different working memory components make a difference? Journal of neuroengineering and rehabilitation, 11(1), 149. doi: 10.1186/1743-0003-11-149

[19] Regnaux, J. P., Robertson, J., Smail, D. B., Daniel, O., \& Bussel, B. (2006). Human treadmill walking needs attention. Journal of neuroengineering and rehabilitation, 3(1), 19. doi: 10.1186/ 1743-0003-3-19

[20] Ruthruff, E., Pashler, H. E., \& Klaassen, A. (2001). Processing bottlenecks in dual-task performance: Structural limitation or strategic postponement? Psychonomic bulletin \& review, 8(1), 73-80. doi: $10.3758 /$ bf03196141

[21] Schaefer, S., Jagenow, D., Verrel, J., \& Lindenberger, U. (2015). The influence of cognitive load and walking speed on gait regularity in children and young adults. Gait \& posture, 41(1), 258-262. doi: 10.1016/j.gaitpost.2014.10.013 
[22] Schrodt, L. A., Mercer, V. S., Giuliani, C. A., \& Hartman, M. (2004). Characteristics of stepping over an obstacle in community dwelling older adults under dual-task conditions. Gait \& posture, 19(3), 279-287. doi: 10.1016/S09666362(03)00067-5

[23] Schulze, C., Lindner, T., Woitge, S., Schulz, K., Finze, S., Mittelmeier, W., \& Bader, R. (2014). Influence of footwear and equipment on stride length and range of motion of ankle, knee and hip joint. Acta of bioengineering and biomechanics, 16(4), 45-51. doi: 10.5277/ABB-00043-2014-02

[24] Shumway-Cook, A., Woollacott, M., Kerns, K. A., \& Baldwin, M. (1997). The effects of two types of cognitive tasks on postural stability in older adults with and without a history of falls. The Journals of Gerontology Series A: Biological Sciences and Medical Sciences, 52(4), M232-M240. doi: 10.1093/gerona/52A.4.M232

[25] Sigman, M., \& Dehaene, S. (2008). Brain mechanisms of serial and parallel processing during dual-task performance. Journal of Neuroscience, 28(30), 7585-7598. doi: 10.1523/ JNEUROSCI.0948-08.2008

[26] Takakusaki, K. (2013). Neurophysiology of gait: from the spinal cord to the frontal lobe. Movement Disorders, 28(11), 14831491. doi: $10.1002 /$ mds. 25669

[27] van lersel, M. B., Ribbers, H., Munneke, M., Borm, G. F., \& Rikkert, M. G. O. (2007). The effect of cognitive dual tasks on balance during walking in physically fit elderly people. Archives of physical medicine and rehabilitation, 88(2), 187-191. doi: 10.1016/j.apmr.2006.10.031

[28] Yogev, G., Giladi, N., Peretz, C., Springer, S., Simon, E. S., \& Hausdorff, J. M. (2005). Dual tasking, gait rhythmicity, and Parkinson's disease: which aspects of gait are attention demanding? European journal of neuroscience, 22(5), 12481256. doi: 10.1111/j.1460-9568.2005.04298.x

\section{СТАТЕВІ ОСОБЛИВОСТІ ХОДЬБИ ПРИ ОДНОЧАСНОМУ ВИКОНАННІ КОГНІТИВНИХ ЗАВДАНЬ \\ Мороз В.М., Йолтухівський М.В., Власенко О.В., Московко Г.С., Богомаз О.В., Рокунець} Л.В., Супрунов К.В.

Організація ходьби та ії порушення залишаються одними із найскладніших розділів фрізіології нервової системи та неврології. Метою роботи $\epsilon$ аналіз статевих особливостей просторово-часових параметрів ходьби людини та напрямків їх змін $в$ умовах виконання додаткових когнітивних завдань. Досліджені статеві особливості ходьби людини при виконанні когнітивних завдань. Обстежено 608 осіб обох статей віком 12-43 років за допомогою системи GAITRite®. В якості когнітивних завдань використано послідовне називання тварин та послідовне віднімання 7, починаючи зі 100. Статистичну обробку отриманих результатів проводили в ліцензійному пакеті "STATISTICA 5.5" з використанням параметричних методів оцінки. При виконанні першого (простішого) когнітивного завдання в усіх вікових групах у чоловіків були більшими довжина кроку та подвійного кроку, співвідношення довжини кроку до довжини кінцівки, ширина бази опори, кути розвороту стоп. Часові параметри у підлітків обох статей не відрізнялись. У дівчат були більшими показники тривалості кроку, крокового циклу, одиночної опори, переносу, проходу й меншою швидкість. Інтегральний показник якості, "нормальності" ходьби (FAP) мав

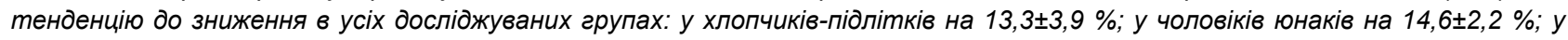

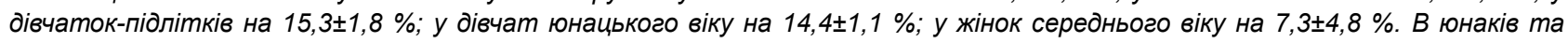
дівчат при виконанні складнішого когнітивного завдання зменшувалися просторові та збільшувалися часові параметри (у першу чергу, за рахунок збільшення тривалості опори на обидві ноги та тривалості переносу ноги), були стабільними ширина бази опори та кути розвороту стоп. Перебудовувався кроковий цикл. Незмінними залишалися ширина бази опори та кути розвороту стоп як у юнаків, так і у дівчат. Юнаки рухалися з більшою швидкістю, виконуючи більшу кількість кроків за хвилину. Час кроку правою ногою, час крокових циклів для кожної ноги, час опори для обох ніг та на дві ноги в дівчат тривали значно довше. Показник FAP критично знижувався на 30,4 \% у юнаків і на 33,4 \% у дівчат, що свідчить про значну реорганізацію базових механізмів регуляції стабільності ходьби. Таке зниження FAP призводить до зниження рівня підтримки рівноваги та зниження стабільності тіла під час руху, а значить - збільшує ризик падінь. Складне когнітивне завдання призвело до зниження якості виконання ходьби та більш критичного зниження якості рахування на користь руху вперед $і$ збереження при цьому рівноваги. Таким чином, ходьба не $є$ автоматизованим процесом, а потребує використання різноманітних додаткових ресурсів ЦНС, насамперед уваги та когнітивних ресурсів.

Ключові слова: просторові параметри ходьби, різні гендерні групи, ходьба з додатковим когнітивним завданням.

\section{ПОЛОВЫЕ ОСОБЕННОСТИ ХОДЬБЫ ПРИ ОДНОВРЕМЕННОМ ИСПОЛНЕНИИ КОГНИТИВНЫХ ЗАДАНИЙ}

Мороз В.М., Йолтуховский М.В., Власенко О.В., Московко Г.С., Богомаз О.В., Рокунец И.Л., Тищенко И.В., Костюк Л.В., Супрунов К.В.

Организация ходьбы и её нарушения остаются одними из наиболее сложных разделов физиологии нервной системы и неврологии. Целью работы есть анализ половых особенностей пространственно-временных параметров ходьбы человека и направлений их изменений в условиях выполнения дополнительных когнитивных задач. Исследованы половые особенности ходьбы человека при выполнении когнитивных заданий. Обследовано 608 лиц обоего пола возрастом 12-43 лет с помощью системы GAITRite®. В качестве когнитивных заданий использовано последовательное называние животных и последовательное вычитание 7, начиная со 100. Статистическую обработку полученных результатов проводили в лицензионном пакете "STATISTICA 5.5" с использованием параметрических методов оценки. При выполнении первого (более простого) когнитивного задания во всех возрастных группах у мужчин были больше длина шага и двойного шага, соотношения длины шага к длине конечности, ширина базы опоры, уәлы разворота стоп. Временные параметры у подростков обоего пола не отличались. У девушек больше показатели длительности шага, шагового цикла, одиночной опоры, переноса ноги, прохода и меньшая скорость. Интегральный показатель качества, "нормальности" ходьбы (FAP) имел тенденцию к

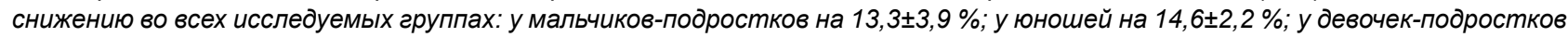

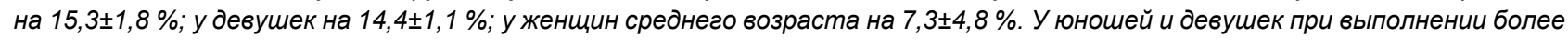
сложного когнитивного задания уменьшались пространственные и увеличивались временные параметры (в первую очередь, 
за счет увеличения длительности опоры на обе ноги и длительности переноса ноги), были стабильными ширина базы опоры и углы разворота стоп. Перестраивался шаговый цикл. Неизменными оставались ширина базы опоры и уәлы разворота стоп как у юношей, так и у девушек. Юноши двигались с большей скоростью, выполняя большее количество шагов за минуту. Время шага правой ногой, время шаговых циклов для каждой ноги, время опоры для обеих ног и на две ноги у девушек длились значительно дольще. Показатель FAP критически снижался на 30,4 \% у юношей и на 33,4 \% у девушек, что свидетельствует о значительной реорганизации базовых механизмов регуляции стабильности ходьбы. Такое снижение FAP приводит к снижению уровня поддержки равновесия и снижению стабильности тела во время движения, а значит увеличивает риск падений. Сложное когнитивное задание привело к снижению качества выполнения ходьбы и более критическому снижению качества счета в пользу движения вперед и сохранение при этом равновесия. Таким образом, ходьба не является автоматизированным процессом, а требует использования разнообразных дополнительных ресурсов ЦНС, прежде всего внимания и когнитивных ресурсов.

Ключевые слова: пространственные параметры ходьбы, временные параметры ходьбы, разные гендерные группы, ходьба с дополнительным когнитивным заданием. 